Citation: S. Dominici, G.D. Rosenberg (2021, Eds.) Nicolaus Steno and Earth Science in Early Modern Italy. Substantia 5(1) Suppl.: 5-17. doi: 10.36253/Substantia-1273

Copyright: (c) 2021 S. Dominici, G.D. Rosenberg. This is an open access, peer-reviewed article published by Firenze University Press (http://www. fupress.com/substantia) and distributed under the terms of the Creative Commons Attribution License, which permits unrestricted use, distribution, and reproduction in any medium, provided the original author and source are credited.

Data Availability Statement: All relevant data are within the paper and its Supporting Information files.

Competing Interests: The Author(s) declare(s) no conflict of interest.

\section{Introduction: Nicolaus Steno and Earth Science in Early Modern Italy}

\author{
Stefano Dominici ${ }^{1}$, Gary D. Rosenberg ${ }^{2}$ \\ ${ }^{1}$ Museo di Storia Naturale, Università degli Studi di Firenze, E-mail: stefano.dominici@ \\ unifi.it \\ ${ }^{2}$ Milwaukee Public Museum \& Earth Sciences Department, Indiana University--Purdue \\ University, Indianapolis, E-mail: grosenbe@iupui.edu
}

Asked to what end one should choose to live, Anaxagoras replied "to study the heaven and the order of the whole cosmos" (Aristotle). ${ }^{1}$

Philosophy is written in this grand book - I mean the Universe - which stands continually open to our gaze, but it cannot be understood unless one first learns to comprehend the language and interpret the characters in which it is written. It is written in the language of mathematics, and its characters are triangles, circles, and other geometrical figures, without which it is humanly impossible to understand a single word of it; without these, one is wandering around in a dark labyrinth. (Galileo Galilei, 1623). ${ }^{2}$

Why would it not be permitted to hope for great things, if anatomy was transformed so that experimental knowledge would rely only on well established facts, and reason accepted only what has been demonstrated; in other words, if anatomy used the language of mathematics? (Nicolaus Steno, 1667) ${ }^{3}$

Galileo's telescope did not prove the validity of Copernicus' conceptual scheme. But it did provide an immensely effective weapon for the battle. It was not proof, but it was propaganda. (Thomas Kuhn, 1957) ${ }^{4}$

Facts contain ideological components, older views which have vanished from sight or were perhaps never formulated in an explicit manner. (Paul Feyerebend, 1975) ${ }^{5}$

\footnotetext{
${ }^{1}$ Aristotles, Ethica Eudemia, in H. Diels, W. Kranz, Die Fragmente der Vorsokratiker, Zürich, 1951, 59 A 30.

${ }^{2} \mathrm{G}$. Galilei, Il saggiatore, nel quale con bilancia esquisita e giusta si ponderano le cose contenute nella libra astronomica e filosofica di Lotario Sarsi Sigensano, Rome, Mascardi, 1623. Quote taken from translation in S. Drake, Discoveries and opinions of Galileo, New York, Doubleday \& Company, 1957, pp. 237-8.

${ }^{3}$ N. Stensen, Canis Carchariae Dissectum Caput, Florence, Stella, 1667 (Canis Carchariae in following notes). English translation in T. Kardel, P. Maquet, Nicolaus Steno, biography and original papers of a 17th century scientist, $1^{\text {st }}$ edition, Heidelberg, Springer, 2013, $594 \mathrm{p}$.

${ }^{4}$ T. Kuhn, The Copernican revolution; planetary astronomy in the development of Western thought. Cambridge, Harvard University Press, 1957, 297 p.

${ }^{5}$ P. Feyerabend, Against method: outline of an anarchistic theory of knowledge. London, New Left Books, 1975, 339 p.
} 


\section{INTRODUCTION}

A group of scientists interested in history of science and fascinated by the figure of Nicolaus Steno (16381686) gathered in Florence for the 350th anniversary of the publication of his De solido intra solidum naturaliter contento prodromus dissertationis. A public conference held at Palazzo Fenzi on 16 October 2019 and a geological fieldtrip on the following day were occasions to discuss different points of view on the last published work of the Danish natural philosopher, dedicated to "solids naturally enclosed in other solids" (De solido intra solidum naturaliter contento, or De solido in short). The title of the gathering, "Galilean foundation for a solid earth", emphasized the philosophical context that Steno found in Florence, where in 1666-1668 he established tight human and philosophical bonds with renowned Italian disciples of Galileo Galilei and members of the Accademia del Cimento. The word "philosophical" then had a different emphasis than it has today.

Born and educated in Copenhagen for a medical degree, student in the hotbed of radical thinkers that was Amsterdam and public debater on human anatomy in Leiden and Paris, Steno was already famous when he moved to Tuscany at the age of 28 , in 1666 . There he found a new type of "anatomical theatre" to carry out the first ideal dissection of the earth and, based on his new and original observations, he wrote a book that is considered a cornerstone of modern geoscience, ${ }^{6}$ marking the passage from the late Renaissance understanding of nature, to a modern, geometric approach to the study of strata, mountains, minerals and fossils. During the Renaissance and early modern period geological objects such as fossils and minerals mattered in the first place for their practical properties, essentially for medical purposes, or out of simple curiosity. As such they belonged to the field of natural history and were studied and collected mainly by physicians and apothecaries. Natural history (from Latin historia, and Greek iotopía, meaning research, knowledge) was a knowledge production tool concerned with the description and classification of natural things, not simply with the record of their past states, as the modern usage of the word "history" implies. ${ }^{7}$ In De solido the same objects became

\footnotetext{
${ }^{6}$ The consequences of Steno's works in the subsequent development of disciplines such as geology and paleontology still need to be freed from anachronistic and teleological tales of "founding fathers" that "fix principles".

${ }^{7}$ The very name of "Museum of Natural History", given in 1775 in Florence to the institution that housed the 2019 conference, testifies that more than a century after De solido natural history was still concerned with organising the products of nature, irrespective of the chronological order of their origins (in a sense, "history" here is a "fossil" word). The
}

instrumental to a reasoning that belonged to philosophy of nature, also called "physics", a vast field concerned with the study of overarching laws of nature. The works of Francis Bacon (1561-1626) in England, Galileo Galilei (1564-1642) in Italy and René Descartes (15691640) in France had radically transformed the point of view of natural philosophers, bringing observation and mathematics to the forefront. As a student of medicine in Copenhagen, Steno came to study fossils and minerals as a natural historian. Both his anatomical and geological writings, however, clearly show that in Florence he developed mathematics as a tool of the philosopher merging the two fields of knowledge. Since he shared this approach with the many disciples of Galileo connected with the Medici court, the question remains why he decided to move and live in Florence during these crucial years of his life.

During Galileo's lifetime, natural philosophy was undergoing a transformation from being based on the textual analysis of classical philosophers, eminently Aristotle (384-322 BC), to become an empirical science based on observation and measurements, aided by technological advancement and qualified by mathematics. ${ }^{8}$ The passage from placing authority on words (of ancient philosophers) to placing it on numbers (collected by the new philosophers) was a slow process taking place simultaneously in several European courts. ${ }^{9}$ If mathematics were already used by ancient and medieval natural philosophers to directly represent physical phenomena, modern scholarship recognizes that "no other episode in the history of Western science has been as consequential as the rise of the mathematical approach to the natural world". ${ }^{10}$ Galileo had shown that to be a natural philosopher meant to be a mathematician and that, if physical phenomena could not always be translat-

modern concept of history as a unidirectional and irreversible process developed starting from the end of the eighteenth century, at the height of the Enlightment, with the influential works of Nicolas de Condorcet (1743-1794) and Thomas Malthus (1766-1834).

${ }^{8}$ Until then applied mathematics were generally considerd of a lower status, because "rather than giving true causal explanations of physical phenomena, rooted in the real natures of the things involved, they just coordinated quantities": P. Dear, "The mathematical principles of natural philosophy: toward a heuristic narrative for the scientific revolution", Configurations, 1998, 6, pp. 173-193. During this transition, "perspective painting, ballistics and fortification, cartography and navigation prepared the ground for Galileo, Descartes and Newton": D. Wootton, The invention of science: a new history of the scientific revolution, Harper Collins, New York, 2015, 784 p.

${ }^{9}$ P. Dear, "Totius in verba: rhetoric and authority in the early Royal Society", Isis, 1985, 76, pp. 144-161.

${ }^{10}$ G. Gorham, B. Hill, E. Slowik, "Introduction", in The language of nature: reassessing the mathematization of natural philosophy in the seventeenth century (Eds. G. Gorham, B. Hill, E. Slowik, K. Waters), Minneapolis, University of Minnesota Press, 2016, pp. 1-3. 
ed into simple mathematical laws, this was simply a sign of the complexity of the mathematical order of nature. ${ }^{11}$ The new natural philosopher had therefore to find new mathematical approaches, a mission that Galileo had handed down to the younger generation.

De solido appeared more than a century before a science of geology became a distinct field of knowledge. ${ }^{12}$ Three hundred and fifty years after that complex historical transition began, participants at the 2019 Florence conference recognised the necessity to contextualise Steno's observations in Tuscany and to explore what factors drove his new interests and what philosophical approach he adopted.

\section{GALILEO GALILEI}

More than a sudden event, the "Scientific Revolution" is generally considered a period spanning 1543 and 1704. In 1543 Vesalius published his anatomical atlas, De humani Corporis Fabrica, and Copernicus sent his letter, known as De revolutionibus orbium coelestium, to the Pope. The publications marked achievements in observational and mathematical science, the former scientifically depicting human anatomy and the latter proposing to replace the Aristotelian, geocentric model of the cosmos with the heliocentric model. In 1704 Isaac Newton (1642-1726) published his Opticks. ${ }^{13}$ Based on the residual strength of classical models, this period can be divided into the Scientific Renaissance (roughly

\footnotetext{
${ }^{11}$ C. R. Palmerino, "Reading the book of nature: the ontological and epistemological underpinnings of Galileo's mathematical realism", in ref. 10, pp. 36-50. Regarding the famous passage from Galileo's Assayer (ref. 2), Palmerino observes that "the chief function of Galileo's use of the metaphor of the book of nature is precisely that of contrasting the exact and 'obligatory' character of mathematical language to the imprecise and arbitrary character of verbal language". On this contrast see also D. Sepkoski, "Nominalism and constructivism in seventeenth-century mathematical philosophy", Historia Mathematica, 2005, 32, pp. 33-59: "early modern natural philosophers did not separate mathematical and scientific pursuits from more general questions in philosophy, so understanding the philosophical basis of their beliefs gives important insight into the development of contemporary mathematical natural philosophy."

${ }^{12}$ M. J. S. Rudwick, Bursting the limits of time: the reconstruction of geohistory in the Age of Revolution. Chicago, University of Chicago Press, 2005, 708 p. The work of Steno was not connected to the emergence of modern geology.

${ }^{13}$ The use of the word "modern" has changed in time and the concept of "scientific revolution" was introduced only in the twentieth century. For an overview see A. Cunningham, P. Williams, "De-centring the "big picture': the origins of modern science and the modern origins of science", The British Journal for the History of Science, 1993, 26, pp. 407432, and L. A. Orthia, "What's wrong with talking about the scientific revolution? Applying lessons from history of science to applied fields of science studies", Minerva, 2016, 54, pp. 353-373. See also P. Dear, and D. Wootton, ref. 6.
}

the sixteenth century) and the true Scientific Revolution (approximately seventeenth century). ${ }^{14}$ Whatever the interval, the innovative approach to the study of the cosmos by Galileo Galilei (1564-1642) represents a discontinuity with the method of predecessors. Since the very late 1650s Galileo's new philosophy came to be qualified as "experimental" because it was based on observational evidences collected through designed experiments ${ }^{15}$ which allowed reading "the book of nature" by the use of mathematics, particularly geometry. This took place in addition or in opposition to the approach inherited from Renaissance philosophers who relied on the analysis of authoritative textual resources. ${ }^{16}$

As a young man, in Pisa and Florence, Galileo practiced mathematics, a discipline in which he stood high, suggesting mathematics was more autoritative in the study of physics than the texts of Aristotle and Aristotelians. In Padua, where he taught geometry, mechanics and astronomy, he started an instrument business, a new science of motion and the study of the skies, offering anti-Aristotelian explanations of celestial phenomena and regarding heliocentrism as preferable. ${ }^{17}$ In 1609 he built his first "telescope" to make distant objects appear much closer. The telescope allowed for crucial observations described in Nuncius sidereus ("the starry messanger"), of $1610,{ }^{18}$ and to convince his skeptics of the validity of his assertions about the Moon and other heavenly bodies. In the words of a twentieth-century scholar: "Galileo's telescope changed the terms of the riddle that the

${ }^{14} \mathrm{P}$. Dear, Revolutionizing the sciences. European knowledge and its ambitions, 1500-1700. Princeton, New Jersey, Princeton University Press, 2001, 200 p. According to other historians the turning point was the discovery of a supernova by Thyco Brahe (1546-1601), proving that the skies are not fixed: "Ptolemaic astronomy was unaffected by Copernicus; it went into crisis with the new star of 1572" (D. Wootton, ref. 8).

15 Experimental natural philosophy, involving "the collection and ordering of observations and experimental reports with a view to the development of explanations of natural phenomena based on these", is sometimes portrayed as an opposition to speculative natural philosophy ("the development of explanations of natural phenomena without prior recourse to systematic observation and experiment”): P. R. Anstey, "Experimental versus speculative natural philosophy", in The science of nature in the seventeenth century: patterns of change in early modern natural philosophy (Eds. P.R. Anstey, J.A. Schuster), Dordrecht, Springer, 2005, pp. 215-242. Against this dichotomy, and reification of philosophy in general, see D. Levitin, "Early modern experimental philosophy. A non-anglocentric overview", in Experiment, speculation and religion in early modern philosophy (Eds. A. Vanzo, P. R. Anstey), New York, Routledge, 2019, pp. 229-291.

${ }^{16}$ P. Dear, refs. 6-7. For a general background on the historiography of mathematization see also G. Gorham, B. Hill, E. Slowik, ref. 10.

${ }^{17}$ J. L. Heilbron, Galileo. New York, Oxford University Press, 2010, 508 p. This is an excellent biography of Galileo and a source also for other subjects dealt with in the present paper.

${ }^{18}$ M. Gargano, "Della Porta, Colonna, and Fontana: the role of Neapolitan scientists at the beginning of the telescope era", Journal of Astronomical History and Heritage, 2019, 22, pp. 45-59. 
heavens presented to astronomers, and it made the riddle vastly easier to solve, for in Galileo's hands the telescope disclosed abundant evidence for Copernicanism." ${ }^{19}$ Galileo himself was aware of his role in society as a philosopher of nature: "beginning with the publication of his Starry Messenger in 1610, Galileo took care - through the letters he wrote, the works he published, and the attention he paid to the preservation of his papers - to portray himself as the instigator of a new way of studying nature". ${ }^{20}$ By 1623, when he published his Il Saggiatore (The assayer), he could safely claim that "philosophy is written in this grand book - I mean the Universe which stands continually open to our gaze, but it cannot be understood unless one first learns to comprehend the language and interpret the characters in which it is written. It is written in the language of mathematics, and its characters are triangles, circles, and other geometrical figures, without which it is humanly impossible to understand a single word of it; without these, one is wandering around in a dark labyrinth." ${ }^{21}$

\section{ACCADEMIA DEI LINCEI}

In 1611 Galileo joined the Accademia dei Lincei ("Academy of the Lynxes") in Rome, which had been congregating there since 1603 around the figure of the young natural philosopher Federico Cesi (1585-1630). The Lincei, and Galileo with them, promoted knowledge about new discoveries, starting with astronomy, ${ }^{22}$ but also including plants, animals and minerals. Thanks to refined Dutch instruments, in 1625 the Lincei published a study on insects including the first printed illustration made with the aid of a microscope, also introduced in

\footnotetext{
${ }^{19}$ T. Kuhn, ref. 4, p. 219. The telescope brought about the immediate and irreversible collapse of Ptolemaic astronomy: D. Wootton, ref. 8.

${ }^{20}$ R. Raphael, Reading Galileo. Scribal technologies and the Two New Sciences, Baltimore, Johns Hopkins University Press, 2017, p. 190. In the last part of the twentieth century epistemologists and historians of science fought over the nature of the "scientific method", positioning Galileo at centerstage: "hardly any other icon of modern science has become as much a victim of his interpreters as Galileo," wrote Klaus Fischer ("Die Wissenschaftstheorie Galileis - oder: Contra Feyerabend", Journal for General Philosophy of Science/Zeitschrift für allgemeine Wissenschaftstheorie, 1992, 23, p. 165-197). Fischer opposed the opinion held by Paul Feyerabend (Against method, see ref. 5).

${ }^{21}$ S. Drake, Discoveries and opinions of Galileo, New York, Doubleday \& Company, 1957, pp. 237-8.

${ }^{22}$ A. C. Scott, Federico Cesi and his field studies on the origin of fossils between 1610 and 1630. Endeavour, 2001, 25, pp. 93-103. D. Freedberg, The Eye of the Lynx. Galileo, his friends, and the beginnings of modern natural history. University of Chicago Press, 2002, 513 p. On the debates following the 1604 supernova see also P. J. Boner, Change and continuity in early modern cosmology. Springer, Dordrecht, 2011, $181 \mathrm{p}$.
}

the Accademia by Galileo. ${ }^{23}$ This group included Italians and foreign members, and formed an interface between learned men pursuing scholarship, like the austere Cesi, and those with more practical interests like the German Johann Faber (1574-1629), in contact with physicians, apothecaries and surgeons. ${ }^{24}$ Their plan for the diffusion of knowledge culminated in 1623-1627 with the publication of the Rerum Medicarum Novae Hispaniae Thesaurus ("History of Mexican plants, animals and minerals", also known as the "Mexican treasure"), a study made possible thanks to the network established by Cesi with Naples and Spain. ${ }^{25}$ An important "lynx" and correspondent to Galileo was the Neapolitan Fabio Colonna (1567-1640), who carried out experiments on the nature of fossils and proposed their organic origin in an appendix at the end of his Ekphrasis (Fig. 1), and in the essay De glossopetris, both of 1616. Colonna was the first to place fossils in a biological context, ${ }^{26}$ a field in which he was well-versed. ${ }^{27} \mathrm{He}$ also understood the promotional importance of illustrating plants, animals and fossils, a task brilliantly achieved through the new technique of etching. ${ }^{28}$ In the end his interpretation of fossils relied more on morphological similarities with modern animals, than on experimental evidence, and his published texts were tightly connected with the erudite tradition inherited from late Renaissance and earlier naturalists. ${ }^{29}$ This confirmed that experimentalism of early Galile-

${ }^{23}$ Several other publications illustratated with images of magnified objects (order of magnification being within the range of twenty to one hundred times) followed in Rome and elsewhere in Europe, until the much better-known images in Robert Hooke's Micrographia of 1665: D. Freedberg, ref. 22, p. 222.

${ }^{24} \mathrm{~S}$. De Renzi, "Medical competence, anatomy and the polity in seventeenth-century Rome", Renaissance Studies, 2007, 21, pp. 551-567. "The sixteenth-century expansion of higher education, the rediscovery and publication of ancient medical and philosophical texts, and the subsequent debates between 'lower' and 'learned' practitioners over who was the true inheritor of ancient traditions all led to the emergence of an institutional debate about the nature of, and relationship between, various natural philosophical disciplines, and a concomitant emphasis that natural knowledge should be derived from experience rather than apriorist reasoning. [...] Since the learned physicians accused the practitioners of being base Empirics, the latter sought to turn the accusation into a positive by elevating the status of experiential knowledge": D. Levitin, ref. 15, pp. 234-235.

${ }^{25}$ Mexican Treasure. Library of Congress, Washington D.C., World Digital Library, https://www.wdl.org/en/item/19340/ (accessed 5 March 2021). See D. Freedberg, ref. 22.

${ }^{26}$ M. J. S. Rudwick, The meaning of fossils. Episodes in the history of paleontology, Chicago, University of Chicago Press, $2^{\text {nd }}$ edition, 1976 [1972], pp. 1-48.

${ }^{27}$ A. Ottaviani, "Fra diluvio noaico e fuochi sotterranei. Note sulla fortuna sei-settecentesca di Fabio Colonna", Giornale Critico della Filosofia Italiana, 2020, 13, pp. 260-271.

${ }^{28}$ Rudwick, ref. 26; Freedberg, ref. 22.

${ }^{29}$ A. Ottaviani, "La natura senza inventario: aspetti della ricerca naturalistica del linceo Fabio Colonna”, Physis, 1997, 34, pp. 31-70. 


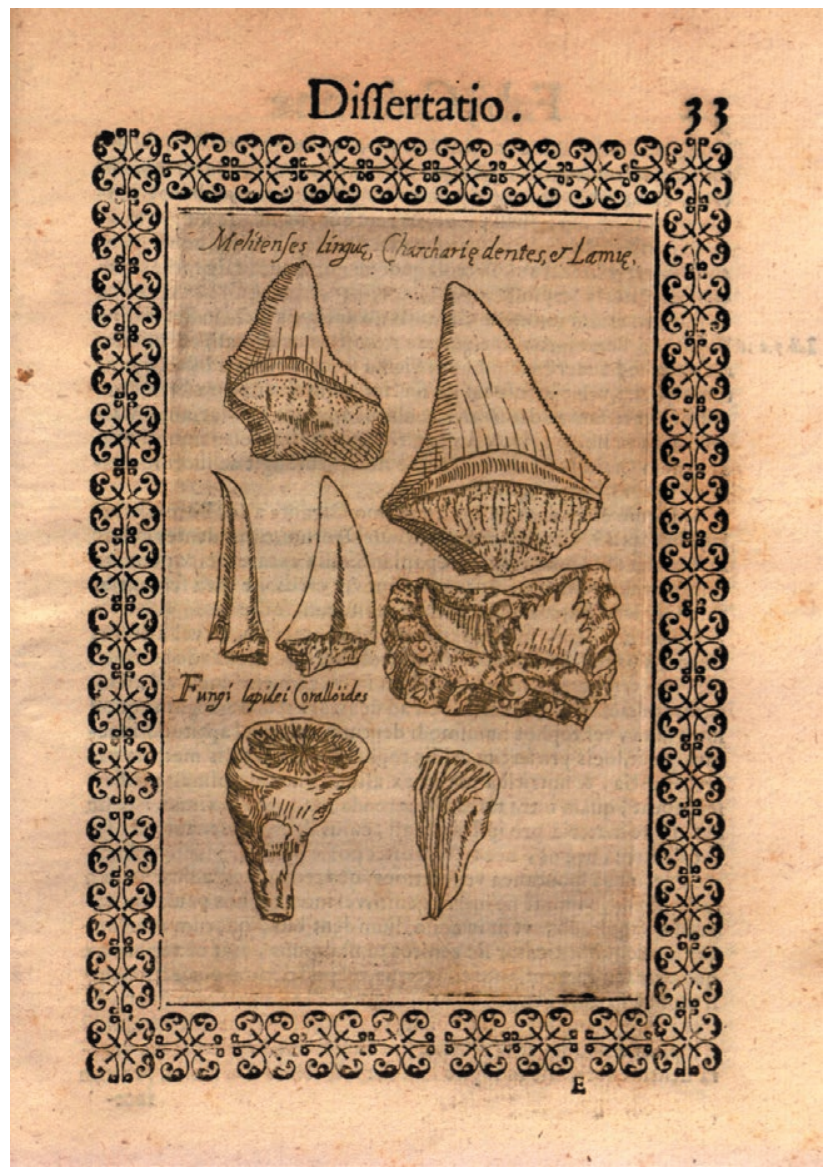

Figure 1. Engraving of fossils from Malta, interpreted as shark teeth ("Melitenses linguae, charchariae dentes et lamiae") in Fabio Colonna's De purpura, aliisque testaceis rarioribus, appendix to his Ekphrasis of 1616. Some fossils are portrayed within the encasing rock. Creative commons, public domain.

ans went hand in hand with the humanistic textual approach transmitted by the scholastic tradition.

The experience of the Lincei as devised by Cesi, who kept contacts with Galileo until Cesi's death in 1630, ended with the definitive edition of the Mexican treasure in 1651. A second academy, directly connected with Galileo's teaching, was founded 15 years after his death. This was called Accademia del Cimento, or "academy of experiment".

\section{THE ACCADEMIA DEL CIMENTO}

After the publication of Galileo's "Dialogue concerning the two chief world systems" in 1632, followed in 1633 by his public recantation of Copernicanism imposed after trial and condemnation by the Roman Catholic inquisition - Galileo spent his last years in
Florence, host of the Grand Duke Ferdinand II of Medici (1610-1670). Here he was visited and assisted by two of his disciples, the mathematicians Evangelista Torricelli (1608-1647) and Vincenzo Viviani (1622-1703). ${ }^{30}$ After Galileo's and Torricelli's deaths, Viviani was among the most active to transmit to posterity Galileo's teachings, mainly by promoting a Galilean agenda through his participation in the Accademia del Cimento. This new Accademia congregated in Florence beginning in 1657 around Prince Leopold of Medici, brother of Grand Duke Ferdinand II. From its inception to about 1660 , members pursued research on the physical world through experiments and observations, led by skilled mathematicians like Viviani himself and the Sicilian Giovanni Alfonso Borelli (1608-1679) and animated by the activity and publications of founding member Francesco Redi (1626-1697) and others, such as Carlo Dati (1619-1676). This activity took place in continuity with that of other leading savants in contact with the Medici court, such as Marcello Malpighi (1628-1694). In 1656 Malpighi had been appointed Professor of theoretical medicine at the University of Pisa, continuing his career in Bologna where in the early 1660s he pioneered the use of the microscope in the study of the human body. ${ }^{31}$ In those same years he undertook a close collaboration on mechanical anatomy and physics (or "iatromachanics") with Borelli, perhaps the most gifted mathematician of the Cimento. ${ }^{32}$ Malpighi, Prince Leopold and other academicians kept contact with learned societies that were flourishing at that time across Europe, so that the Italians were an integral part of that community of natural philosophers and humanists called the "Republic of Letters". ${ }^{33}$

Lorenzo Magalotti (1637-1712), secretary since 1660, compiled a collection of the Cimento experiments and published it in 1667 with the title Saggi di natura-

\footnotetext{
${ }^{30}$ J. L. Heilbron, Galileo. New York, Oxford University Press, 2010, 508 p. ${ }^{31}$ According to D. Wootton, "between 1661 and 1691 more was discovered in biology than in any other generation since the death of Aristotle". This interest for a new type of observation, fuelled by expectation of economic gains, motivating investors like the Medici, gradually waned: "In the seventeenth century, Descartes had promised that sound natural philosophy would lead to a new medicine that would enormously extend life expectancy; by the end of the century even French Cartesian doctors had reconciled themselves to traditional medicine:" D. Wootton, Bad medicine: doctors doing harm since Hippocrates, Oxford University Press, 2007, $336 \mathrm{p}$.

32 M. Malpighi, The Correspondance of Marcello Malpighi (Ed.: H. B. Adelmann), Cornell University Press, Ithaca-London, 1975, 1, pp. 318319. See also L. Boschiero, "Introduction", in Borelli's On the Movement of Animals. On the Force of Percussion (Tr.: P. Maquet), Brill, Leiden, 1989, p. i-xxi.

${ }^{33}$ R. Rappaport, When geologists were historians, Cornell University Press, Ithaca and London, 1997, 308 p.
} 


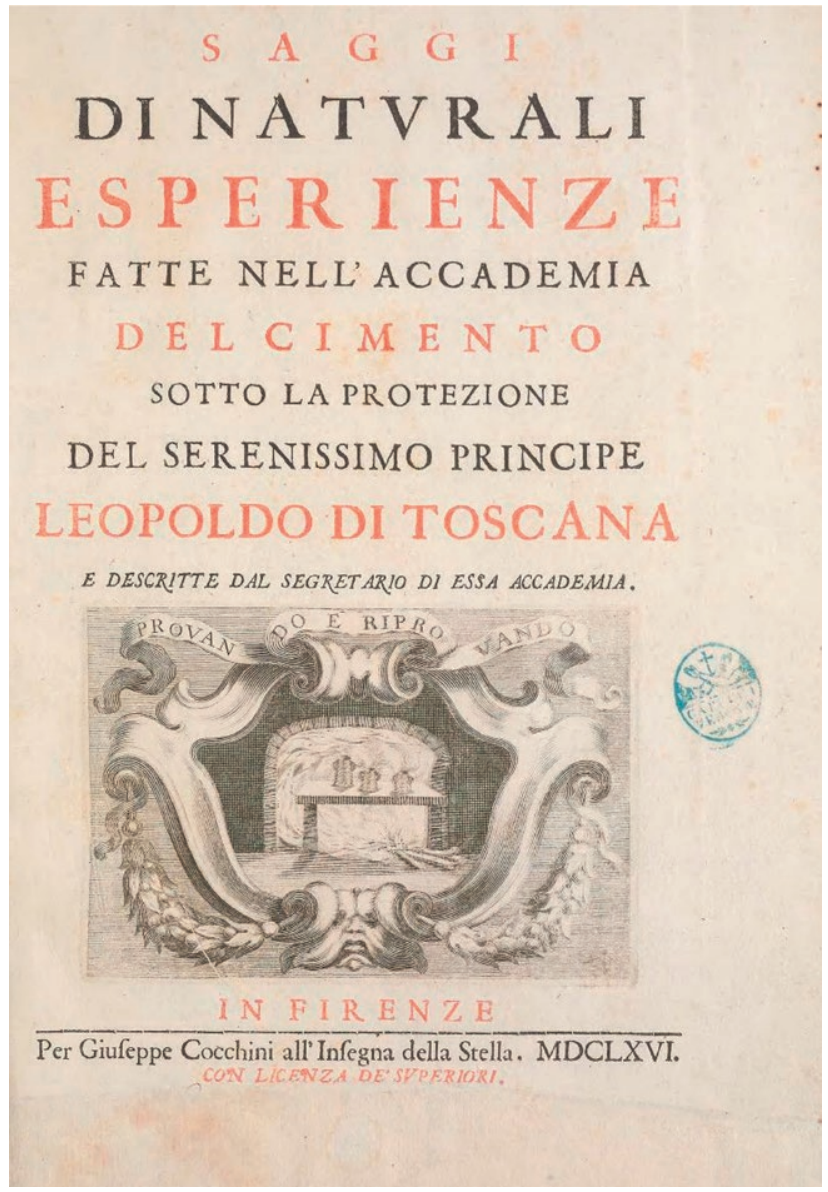

Figure 2. Frontispiece of Saggi di Naturali esperienze by Lorenzo Magalotti and including the description of the experiments carried out in 1657-1660 at the Accademia del Cimento, in Florence. The book expressed part of the philosophical approach of disciples of Galileo at the Medici court. It was published in 1667, a few months after Steno's arrival there. Creative commons, public domain.

li esperienze (Fig. 2). ${ }^{34}$ Probably to avoid controversies among members of the academy, Magalotti intentionally excluded debates about theory, giving the appearance of a non-speculative approach, at the same time boosting the idea that Galileo had started and transmitted a new method to the academy, one to produce atheoretical, fac-

\footnotetext{
${ }^{34}$ L. Magalotti, Saggi di naturali esperienze fatte nell'Accademia del Cimento sotto la protezione del Serenissimo Principe Leopoldo di Toscana e descritte dal segretario dell'Accademia, Florence, Giuseppe Cocchini all'Insegna della Stella, 1667, 286 p. Translated "Experiments in natural philosophy" in the fundamental study by W. E. K. Middleton, The experimenters: a study of the Accademia del Cimento, Baltimore, Johns Hopkins University Press, 1971, 415 p. See also L. Boschiero, Experiment and natural philosophy in seventeenth-century Tuscany. The history of the Accademia del Cimento, Springer, Dordrecht, 2007, 251 p., and M. Beretta, M. Feingold, P. Findlen, L. Boschiero, "Regress and rhetoric at the Tuscan court", Metascience, 2010, 19, pp. 187-210.
}

tual knowledge of nature by experiments. Complex relations, different temperaments and rivalry between academicians have in part hindered the reconstruction of the philosophical debate taking place in Florence in 16571667. It is nevertheless clear that those debates testify to a fervent activity of research and of the ability of Prince Leopold to establish an environment where different approaches to natural philosophy could coexist. ${ }^{35}$

\section{EUROPE AND THE NEW PHILOSOPHY}

Galileo's writings influenced the work of three natural philosophers of the Scientific Revolution in France. The first was Marin Mersenne (1588-1648), who translated in French and promoted Galileo's Discourse one year after its publication and repeated some of the "experiences" of the Italian. ${ }^{36}$ The second was René Descartes (1569-1640), who was marginally interested in Galilean writings and seemed more critical, ${ }^{37}$ but nevertheless succinctly recognised in 1638 that Galileo's teaching was revolutionary because it abandoned "the errors of the schools and [brought] mathematics to bear on problems in physics". 38

As did Galileo, Descartes rejected Aristotelian physics, and replaced it with a physics grounded in a mechanistic conception of nature, one that could be approached with mathematics. According to the French philosopher, the universe is made of void and of particles that can freely move by inertia, eventually colliding one with another. The fortune of Cartesian atomistic cosmology, circulating in the 1630s and published posthumously in Paris in 1664 with the title Traite $d u$ monde et de la lumière, ${ }^{39}$ reached behind the evident flaws of the laws of inertial motion proposed by its author, and continued to inspire through the seventeenth century many aspects of natural philosophy. In astronomy it offered explanation to planetary motion, necessary for a self-consistent Copernican system. Johannes Kepler (1571-1630) had devised a mechanistic solar system

${ }^{35}$ P. Findlen, in M. Beretta, M. Feingold, P. Findlen, L. Boschiero, ref. 34, p. 204.

${ }^{36}$ R. Raphael, "Galileo's Discorsi and Mersenne's Nouvelles pensées: Mersenne as a reader of Galilean 'experience,' "Nuncius, 2008, 23, pp. 7-36. C. R. Palmerino, "Experiments, mathematics, physical causes: how Mersenne came to doubt the validity of Galileo's law of free fall," Perspectives on Science, 2010, 18, pp. 50-76.

${ }^{37}$ W. R. Shea, "Descartes as critic of Galileo", New perspectives on Galileo (Eds. R. E. Butts, J. C. Pitt), Dordrecht, Reidel, 1978, pp. 139-159; R. Ariew, "Descartes as critic of Galileo's scientific methodology", Synthese, 1986, 67, pp. 77-90; R. Raphael, ref. 19.

${ }^{38}$ Letter to M. Mersenne of 11 October 1638, in R. Ariew, ref. 37, p. 81.

${ }^{39}$ R. Descartes, Traité du monde et de la lumière, Paris, Girard, 1664 [1633], $260 \mathrm{p}$. 
governed by forces that move the planets around the sun. In the light of the concept of inertial motion introduced by Descartes, Kepler's system was amended by Borelli in $1666,{ }^{40}$ and separately, but simultaneously, by Robert Hooke (1635-1703) in England. ${ }^{41}$ Finally, philosophy of knowledge, or epistemology, was at the core of Descartes' Discours de la méthode (1637), a brief but influential book about method in science. ${ }^{42}$

The third key figure of the new philosophy in France was Pierre Gassendi (1592-1655), an experimenter who also followed in the footsteps of Galileo. ${ }^{43}$ Differently from Descartes, who in his Principia philosophiae of 1644 had proclaimed that there cannot be indivisible atoms, Gassendi proposed that primordial atoms may combine with one another to form larger and structured particles called "molecules". The French scenario developed until an institution similar to the Accademia del Cimento started in Paris, the Académie Royal des Sciences. This was formally founded in 1666 , preceded by the work of informal academies that had been gathering there since $1661 .^{44}$

The Gassendian approach was embraced in England by Robert Boyle (1627-1691), who brought the atomic and mechanical philosophies within the compass of experiment with the publication in 1661 of Nova experimenta physico mechanica. ${ }^{45}$ One year earlier, Boyle had been one of the founding members of the Royal Society of London, the British analogue of the Florentine institution which, on matters concerning experimental philosophy, inherited the teachings of Francis Bacon and of the Oxford school. ${ }^{46}$ Boyle adopted a "vitalistic corpuscularianism" and the experiments proposed by the iatrochemist Daniel Sennert (1572-1637) and the alchemical atomist Jan Baptist van Helmont (1580-1644). ${ }^{47}$ The

\footnotetext{
${ }^{40}$ G. A. Borelli, Theoricae mediceorum planetarum ex causis physicis deductae, Florence, S.M.D., 1666, 184 p.

${ }^{41}$ T. Kuhn, ref. 4, p. 237-260.

${ }^{42}$ D. Garber, Descartes embodied. Reading Cartesian philosophy through Cartesian science, Cambridge University Press, 2000, 337 p.

${ }^{43}$ R. Raphael, ref. 20

${ }^{44}$ N. Dew, Orientalism in Louis XIV's France, Oxford University Press, Oxford, 2009, $301 \mathrm{p}$.

${ }^{45}$ M. P. Banchetti Robino, The chemical philosophy of Robert Boyle. Mechanicism, chymical atoms, and emergence, New York, Oxford University Press, 2020, $196 \mathrm{p}$.

${ }^{46} \mathrm{R}$. Jr Frank, Harvey and the Oxford physiologists: scientific ideas and social interaction, Berkeley, University of California Press, 1980, 368 p.; M. C. W. Hunter, Establishing the new science: the experience of the early Royal Society, Woodbridge, Boydell, 1989, 382 p.; D. Levitin, ref. 15. For Bacon see also D. Jalobeanu, "The marriage of physics with mathematics". Francis Bacon on measurement, mathematics, and the construction of a mathematical physics", in ref. 10, pp. 51-80.

${ }^{47}$ M. P. Banchetti Robino, The chemical philosophy of Robert Boyle. Mechanicism, chymical atoms, and emergence, New York, Oxford University Press, $196 \mathrm{p}$.
}

new practice of studying the inner nature of matter and its transformations was then called "chymistry". In the Dutch Republic, perfected microscopes were opening a window into the minutest parts of nature such as insects, showing "the wonders of God in the humblest creatures". New observations were influential during the 1660 s, driving the transformation of museums "from collections of curiosities to cabinets of naturalia." 48

In conclusion, during the years of activity of the Accademia del Cimento (1657-1667), when Steno received his formal education and made some of his most influential discoveries, an impressive series of panEuropean events was shaping natural philosophy in an unprecedented way. The new "experimental philosophy", as it was also called then in England, ${ }^{49}$ did not however break abruptly with the traditional approach, but remained in many ways connected with the humanistic tradition of reading ancient texts and interpreting them in the light of the new approaches to the study of nature. ${ }^{50}$

A particular case related to the quintessential book, the Bible. If the works of Aristotle or other classics were rediscovered during the late Middle Ages and the Renaissance, biblical exegesis had been practised at the highest levels without interruption for two thousand years and taught in European universities for centuries. Theology, and biblical scolarship with it, at least in part adapted to the new philosophy of nature by a process of inclusion, so that the learned Anglican bishop Edward Stillingfleet (1635-1699) could write in 1662 that "the best way to cure the world of atheism is true philosophy, or a search into the natures of things; which the more deep and profound it is, the more impossible will it be found to explicate all the phenomena of nature by mere matter and motion." 51 The early modern period was however also a time when skepticism towards its literal interpretation grew. ${ }^{52}$ Textual criticism came to be

${ }^{48} \mathrm{E}$. Jorink, Reading the book of nature in the Dutch golden age, 15751715, Brill, Leiden, 2010, 472 p.

${ }^{49}$ A. E. Shapiro, "Newton's "Experimental Philosophy"', Early Science and Medicine, 2004, 9, pp. 185-217.

${ }^{50}$ D. Levitin, ref. 15 .

${ }^{51}$ E. Stillingfleet, Origines sacrae: or a rational account of the grounds of the Christian faith, as to the truth and divine authority of the scriptures, and the matters therein contained, London, Mortlock, 1662, p. 408. See also S. Hutton, "Science, philosophy, and atheism. Edward Stillingfleet's defence of religion", in Skepticism and irreligion in the seventeenth and eighteenth centuries (Eds. R. H. Popkin, A. J. Vanderjagt), Amsterdam, Brill, pp. 102-120.

${ }^{52}$ For the role of these freethinkers in their cultural environments see R. H. Popkin, A. J. Vanderjagt, Skepticism and irreligion in the seventeenth and eighteenth centuries, Amsterdam, Brill, 374 p.; A. Hessayon, N. Keene, Scripture and scolarship in early modern England, Ashgate, Aldershot, Hampshire, 2006, 255 p.; E. Jorink, "Horrible and blasphemous": Isaac La Peyrère, Isaac Vossius and the emergence of radical 
openly discussed across different Christian confessions, such as in the work of the Protestants Isaac La Peyrère (1596-1676) and Isaac Vossius (1616-1689), the Anglican Francis Lodwick (1616-1694) and the Catholic Richard Simon (1638-1712). The most influential critic was the Jewish philosopher Baruch Spinoza (1632-1677), who adopted a form of natural religion in his Ethica, ordine geometrico demonstrata ("Ethics, demonstrated in geometrical order"), written between 1661 and 1675, a book that fuelled debate. ${ }^{53}$ Notwithstanding the first burst of textual criticism of modernity, from Peyrère's "Praeadamites" of 1655 to Spinoza's "Ethics" of 1675, most seventeenth-century natural philosophers did not doubt that the first book of the Bible, the book of Genesis, was a reliable historical account of the distant past. Its understanding needed interpretation, the reason why a science of biblical chronology became a necessity, from the early works of 1642-1655 of John Lightfoot (16021675) and James Ussher (1581-1656), to that of Isaac Newton in the early eighteenth century. ${ }^{54}$

\section{NICOLAUS STENO}

At the age of 21 in 1659, while a student of anatomy at the Copenhagen Medical School, Steno kept a private journal in which he collected excerpts from, and wrote comments on, the books he and his teacher Ole Borch (1626-1690) read.55 Titled "Chaos", this journal indicates that Steno's readings went beyond strictly medical matters needed in his university curriculum. He evidently aimed at an "understanding of the whole cosmos", to use Aristotles' words, ${ }^{56}$ and not simply at becoming a court physician, or the Danish Royal Anatomist he later became. ${ }^{57}$ Many of the excerpts relate to philosophical and methodological subjects. Regarding Galileo, Steno excerpted a passage from Sidereus Nuncius as it applied

biblical criticism in the Dutch Republic," in Nature and Scripture in the Abrahamic religions: up to 1700 (Eds. J. M. van der Meer, S. Mandelbrote), Brill, Leiden, 2016, pp. 429-450.

${ }^{53} \mathrm{R}$. Rappaport in ref. 33, p. 76. Criticism towards historicity of the biblical narrative was discussed only privately, and in small circles: see an eloquent example in W. Poole, "The Genesis narrative in the circle of Robert Hooke and Francis Lodwick", in Scripture and Scolarship in Early Modern England (Eds. A. Hessayon, N. Keene), Ashgate, Aldershot, Hampshire, 2006, pp. 41-56.

${ }^{54}$ M. J. S. Rudwick, Earth's deep history. Chicago University Press, Chicago, 2014, pp. 9-30.

${ }^{55}$ A. Ziggelaar, "Niels Stensen's Chaos-manuscript Copenhagen, 1659. Complete edition with introduction, notes and commentary", Acta Hist. Sci. Nat. Med., 1997, 44, p. 301-302.

${ }^{56}$ Aristotle, ref. 1.

${ }^{57}$ G. Scherz, "Biography of Nicolaus Steno", in ref. 2 (Kardel, Maquet), pp. 6-346. to a test for telescopes. ${ }^{58}$ An interest in telescopes was coupled with a possibly greater fascination with microscopes, which, similarly to Galileo's telescope, posed the problem of sensory perception, whether the instruments revealed natural phenomena or artifacts of the technology. Steno wrote passages in his journal on the use of microscopes that related to different topics such as optic aberration, refraction, and geometric shapes seen in tiny crystals that appear round to the naked eye. ${ }^{59}$ Regarding corpuscularism, he extensively excerpted the writings of Pierre Gassendi and Ole Borch, and used the word corpuscula ("tiny particles") 43 times in his journal, seeking to explain through atomistic theory disparate phenomena such as light, magnetism, colour, senses, changes in state, and the chemical behaviour of different solids and fluids. ${ }^{60}$ This research reached its climax in 1666-1668, when corpuscular theory had became an integral part of the Florentine writings, ${ }^{61}$ the word corpuscula being meanwhile substituted by particulas (repeated 36 times in the 78 pages of De solido). Sennert's Institutionum medicinae libri $V$ was a book that in 1659 he read with enthusiasm and excerpted only on medical matters, but where he would have learned about an influential look on atomism in chemistry.

Descartes had brought method to centerstage. Steno widely read and excerpted the French philosopher, declaring in 1659 that he was willing to work "more accurately and orderly following Descartes' method."62 In the first year of his stay in Florence he publicly praised Descartes' lesson in the use of mathematics as a means to true knowledge: "whoever thinks that its true understanding can be sought without mathematical assistance must also think that there is matter without extension, and body without figure."63 In Florence he

${ }^{58}$ A. Ziggelaar, in ref. 55, pp. 301-302.

59 The journal of 1659 contains five passages on microscopes: A. Ziggelaar, in ref. 55, p. 290, 292, 296, 395, 396.

${ }^{60}$ A. Ziggelaar, in ref. 55. "Clavis chymiae verae desideratur," Steno wrote, meaning "the key of true chemistry is wanted": p. 127).

${ }^{61}$ A. Clericuzio, "Meccanicismo ed empirismo nell'opera di Steensen", in Scienza, filosofia e religione nell'opera di Niels Steensen (Eds.: M. A. Vitoria, F. J. Insa Gómez), Pagnini, Firenze, p. 123-138.

${ }^{62}$ A. Ziggelaar, in ref. 55, p. 123.

${ }^{63}$ N. Stensen, Elementorum myologiae specimen, seu musculi descriptio geometrica, in T. Kardel, P. Maquet, ref. 3, p. 547, and references therein. See also S. Olden-Jørgensen, "Nicholas Steno and René Descartes: a cartesian perspective on Steno's scientific development," in The Revolution in geology from the Renaissance to the Enlightenment (Ed. G. D. Rosenberg), Geol. Soc. Am. Mem., 2009, 203, 149-157. Olden-Jørgensen sees all of Steno's works as "operated within a securely Cartesian world" (p. 155). Application of the Cartesian method of doubt led Steno to experiment with new hypotheses in anatomy and new methods of dissection: V. Grigoropoulou, "Steno's critique of Descartes and Louis de La Forge's response," in Steno and the philosophers (Eds. R. Andrault, M. Lærke), Brill, Leiden, 2018, p. 113-137. A critical view on Steno's cartesianism, and his debts to Pierre Gassendi and Francis Bacon, is found in A. Clericuzio, ref. 61. 
interacted with some of the most learned mathematicians of his time, including perhaps the two most notable Galileans Vivani and Borelli. This he did in coincidence with the publication of the ultimate work on the activities of the Accademia del Cimento, the Saggi di naturali esperienze (Fig. 2) ${ }^{64}$ Scholars are of the opinion that Steno was influenced by the Florentine method, particularly in De solido, by the deliberate adoption of "experience" as advocated in the Saggi as historia. Through the narration of experiments, historia was a form of empirism that focused on experience and challenged the scholastic approach of Aristotelian speculations about philosophical causes. ${ }^{65}$ At the same time Steno distanced himself from the inductivist attitude expressed in the Saggi ${ }^{66}$ by remaining a natural philosopher, interested in causal investigation. ${ }^{67}$

\section{A SCIENCE FOR THE EARTH}

The main subject matter of De solido, earth materials, such as strata, minerals and fossils, served as an attempt to establish a general method in the study of nature and a scale-independent means to disclose chronology of events in earth's history. The interest in fossilia, or res metallica (meaning anything dug up from the earth), had been emerging during the late Renaissance within the wider realm of natural history. Natural history was the job of keepers of museums, whether private such as that of Ferrante Imperato (1525-1615), or attached to public institutions, such as that of the Vatican Metallotheca in Rome, kept by Michele Mercati (1541-1593), and that of the Gallery of the University of Pisa, first organised by Andrea Cesalpino (1524-

\footnotetext{
${ }^{64}$ L. Magalotti, ref. 26.

${ }^{65} \mathrm{~J}$. Bek-Thomsen, From flesh to fossils - Nicolaus Steno's anatomy of the Earth, in A history of geology and medicine (Eds.: C. J. Duffin, R. T. J. Moody, C. Gardner-Thorpe). Geological Society of London, Special Publications, 2013, 375, 17 p.; J. Bek-Thomsen, Steno's historia: methods and practices at the court of Ferdinando II, in ref. 13 (Andrault, Lærke), p. 233-258.

${ }^{66} \mathrm{P}$. Findlen, Controlling the experiment: rhetoric, court patronage and the experimental method of Francesco Redi, History of Science, 1993, 31, p. 35-64; L. Boschiero, Experiment and natural philosophy in seventeenth-century Tuscany. The history of the Accademia del Cimento, Springer, Dordrecht, 2007, 251 p. Borelli, who contributed his thoughts to the Saggi, was particularly concerned to present the work of the Accademia as the accumulation of knowledge through rigorous experimenting, free of any theorising (Boschiero, p. 185). Inductivism is the view that science proceeds via generalization from facts recorded in basic sentences: J. Preston, Feyerabend, philosophy, science and society. Cambridge, Polity press, $234 \mathrm{p}$.

67 "Steno was not writing as an anatomist or court physician but as a natural philosopher:” J. Bek-Thomsen, ref. 15b, p. 251
}

1603).$^{68}$ In the late 1650 s and early 1660 s, a number of phenomena relating to fossilia were attracting the attention of natural philosophers, as they had a few years earlier attracted Fabio Colonna in Rome (Fig. 1). Steno's elder competitors in this field were Athanasius Kircher (1602-1680) in Italy, Pierre Borel (1620-1671) in France, Ole Borch in Denmark and Robert Boyle (1627-1691) in England. In Florence, the young Dane proposed the first coherent and modern solution to explain the origin of fossils together with that of the strata that enclosed them. Anticipated by the publication of Canis carchariae dissectum caput, hastely written and published in 1667 (Fig. 3), his theory was briefly, but completely exposed in De Solido, published in $1669 .{ }^{69}$ Both essays had immediate feedback in Europe.

The early modern period had become a time of travels in the explicit search of historical evidences of natural events. Noteworthy European travellers who interacted with Steno and who published essays on fossils (although the relationship among their travels and the study of fossils is not always clear), were his teacher in Copenhagen Thomas Bartholin $(1616-1680)^{70}$ and the early Fellows of the Royal Society of London, John Ray (1627-1705), Martin Lister (1638-1712) and Robert Hooke. ${ }^{71}$ Philosophy of nature in the widest sense was at stake, not simply the explanation for the existence of "figured stones" or sports of nature. Common destinations for such travels were Montpellier, Sicily and Malta, where fossils are dug up in abundance to the present day. Agostino Scilla (1624-1700), another contemporaneous contributor to the debate on the origin of fossils, ${ }^{72}$ could study them in his homeland, Sicily, a richly fossiliferous region. Steno, after travelling to Montpellier,

${ }^{68}$ L. Tongiorgi Tomasi, Giardino dei semplici. L’orto botanico di Pisa dal XVI al XX secolo (Eds.: F. Garbi, L. Tongiorgi Tomasi, A. Tosi), Pacini, Ospedaletto, 1986, pp. 161-170; M. J. S. Rudwick, ref. 26; P. Findlen, Possessing Nature: museums, collecting and scientific culture in early modern Italy University of California Press, Berkeley, 1994, 449 p.

${ }^{69} \mathrm{~T}$. Yamada, Hooke-Steno relations reconsidered: reassessing the roles of Ole Borch and Robert Boyle, in G. D. Rosenberg, ref. 7, p. 107-126. M. Romano, "'The vain speculation disillusioned by the sense': the Italian painter Agostino Scilla (1629-1700), called 'The Discoloured', and the correct interpretation of fossils as 'lithified organisms' that once lived in the sea," Historical Biology: An International Journal of Paleobiology, 2014, 26, p. 631-651.

${ }^{70}$ G. Scherz, Niels Stensen eine Biographie, 1987, translated in ref. 2 (Kardel, Maquet), p. 7-346. A. Ottaviani, "Officiosissimam salutem nomine meo nunciabis $\mathrm{Cl}$. viro Mario Schipano parentis amico veteri, quem laetus humanis adhuc interesse accepi, utinam diu": memorie di viaggio e viaggio nella memoria nel tour italiano di Thomas Bartholin. Schede umanistiche: rivista semestrale dell'Archivio Umanistico Rinascimentale Bolognese, 2, 2004, pp. 89-110.

${ }^{71}$ M. J. S. Rudwick, ref. 54, p. 49-100.

${ }^{72}$ Although never mentioning him, Scilla had surely heard about Steno's works through John Ray and Giovanni Alfonso Borelli: see P. Findlen, ref. 68 . 


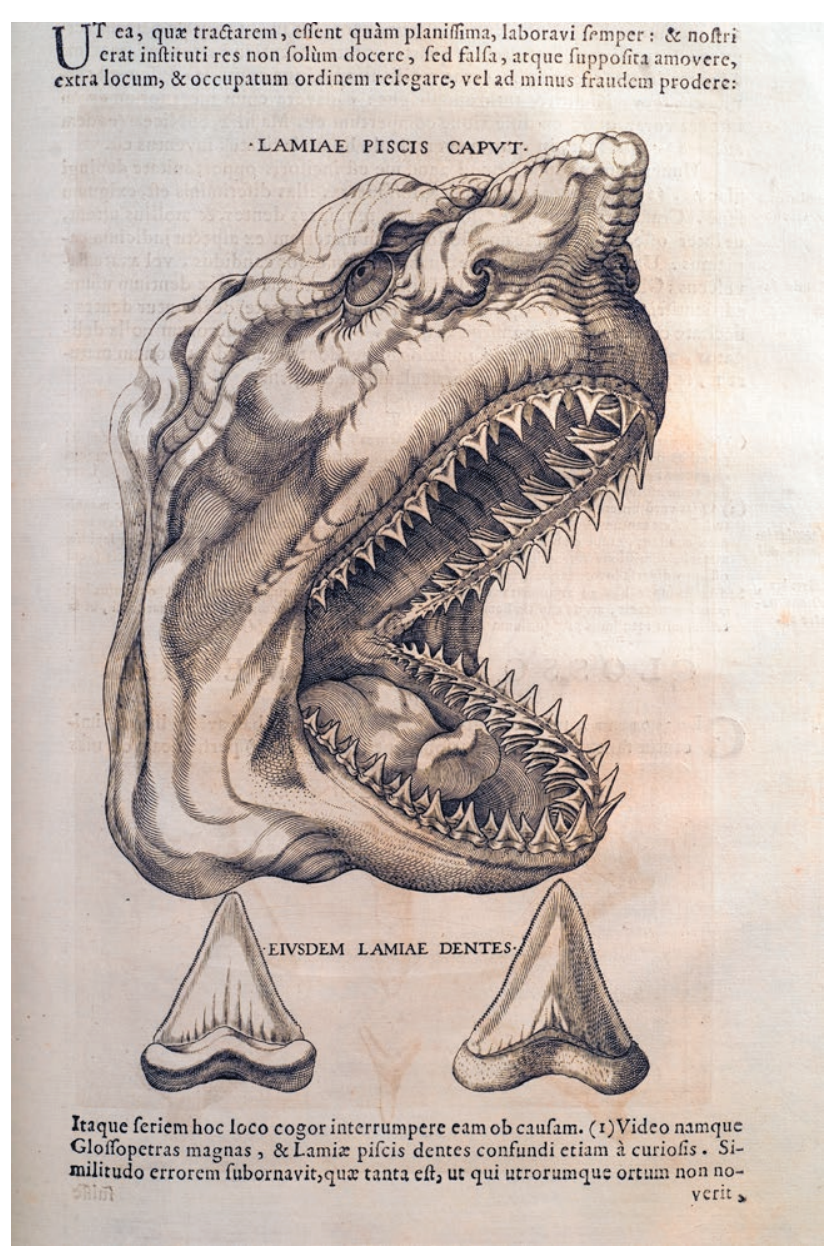

Figure 3. Portrait of a shark's head by Anton Eisenhoit (1553-1603), originally engraved around 1590 for Michele Mercati's Metallotheca Vaticana (published postumously in 1717) and used by Steno in 1666 to illustrate his Canis carchariae dissectum caput. Photograph by Saulo Bambi, reproduced with permission from Metallotheca Vaticana, courtesy of the Botanical Library of the Florence University.

had found in Tuscany the perfect place to immediately set out to work and study the natural setting where fossils were found, finally merging history of the earth with animal anatomy and corpuscular theory ${ }^{73}$

By the time Steno's two "geological" works were translated and published by the Royal Society of London, in 1671, his primary interest in natural philosophy was waning, gradually substituted by the study of theology, seen as superior to the first as a way to truth (he became priest in 1675). Nevertheless, by combining the laws of physics and geometry with historical process and biblical scolarship, he had inaugurated a fruitful period in the study of the earth. This fluorished

\footnotetext{
${ }^{73}$ A. Clericuzio, ref. 61.
}

in the publication of a series of other theories, particularly among philosophers of the Royal Society, each one proposing his own take on merging natural history with the reports of human witnesses, centered in the book of Genesis and the tale of the universal deluge. The sheer number of theories of the earth published in 1669-1695, from those by John Ray, Martin Lister and Robert Hooke, to those of Thomas Burnet (1635-1715) and John Woodward (1665-1728), together with the fantasies of their constructs, gained their authors the title of "world makers". ${ }^{74}$ By the time Steno died, in 1686 the focus of many learned men around him had gradually changed, no longer emphasizing mathematics as the language of the universe, but speculating on earth's history so as to merge physics with the biblical narrative. "Theory of the earth", or geotheory, became a genre, cultivated through the eighteenth century throughout Europe and culminated in the work of Louis Buffon (1704-1788), with his world-famous Les époques de la nature (1778). When Jean-Baptiste Lamarck (1744-1829) in France published his own geotheory in 1802 with the title Hydrogélogie, the genre had gone out of fashion among savants. Younger researchers had learned to start off from scratch once again. This they did by avoiding speculations and concentrating on the reconstruction of historical facts through the analysis of stratal relationships and the punctiform record of fossil occurrences of their own region. The leading figures of this new science, performed with hammer in hand in field activities and by study of museum collections, were Georges Cuvier (1769-1832) and Alexandre Brongniart (1770-1847) in France, Giambattista Brocchi (1772-1726) in Italy, and George Bellas Greenough (1778-1855) and William Buckland (1784-1856) in England. What they were doing was being called "geology" for the first time. ${ }^{75}$

\section{THE THEMATIC VOLUME}

For participants to the 2019 gathering, the Museum of Natural History of the University of Florence, hosting some of Steno's geological specimens, and the region of Tuscany itself, formed the perfect location to discuss the phenomena that Steno had observed from 1666-1668, the motivations for his research, the methodology of his discovery and, generally stated, the European scientific context which informed his inquiry. Some of the talks given in that meeting are included within this volume, kindly hosted by Substantia, International Journal of the History of Chemistry published by the Florence University

\footnotetext{
${ }^{74}$ M. J. S. Rudwick, ref. 26, p. 49-100; R. Rappaport, ref. 33.

${ }^{75}$ M. S. J. Rudwick, ref. 54
} 
Press. In addition some of the invited speakers who were unable to attend, also contributed a paper to this publication. The collection is about earth science in the early modern period, when the study of minerals, rocks, and the fossilized remains of living things did not yet form a distinct path to knowledge about earth history, but was an integral part of the wider "philosophy of nature".

Participants to the thematic volume came from different parts of the world and from different backgrounds. Some are historians of science, others are physicians and geologists, with an experience in either medicine, mineralogy, paleontology or geochronology. Each understood from a particular point of view what observation, the experimental method, and use of geometry meant to early modern natural philosophers active in Italy, whether interested in the study of muscles, fossils, crystals or sedimentary strata.

Their papers in this volume contribute to understanding Nicolaus Steno's natural philosophy in the context of $17^{\text {th }}$ century Europe. They reveal Steno and his contemporaries' interest in structure, origins, processes, and history of earth materials and fossil remains in a way that constitutes a glimpse into early attempts to understand natural history as we now understand it, even as many early conceptions of that story retained remnants of biblical and Aristotelian ideas. Stated a bit differently, the ideas in this volume bear on understanding the beginnings of the science of natural history, or evolution, as it is understood today.

Nicolaus Steno was a Galilean in the company of other Galileans, natural philosophers who largely shunned traditional scholastic speculations and valued instead observation and use of mathematics to describe nature and reveal its mysteries. The identification and description of scientific detail of the objects of nature rocks, stones, fossils, animals, and plants - which is a recurrent theme in the volume - are pre requisites for understanding their evolution.

Alessandro Ottaviani's tour de force study of primary sources details the status of theories in the $17^{\text {th }}$ century for the origin of stones and fossils (which then were anything dug up from the earth). Fabio Colonna did, however, predate Steno in recognizing that fossils are the remains of once-living things, but he invoked an Aristotelian model of material causes (water and earth) and efficient causes (heat and cold) for the origin of stones. Other natural philosophers, such as Federico Cesi, and Francesco Stelluti had advocated origin of fossils by various Aristotelian vegetal or plastic forces. And Cesi went further and adopted the idea of the continuum of divine creation, the Great Chain of Being, a classification scheme in which angels occupied a position closest to divinity followed successively by humans, animals, plants, and finally stones, any one of which could undergo degeneration, moving it farther away from divinity.

Nuno Castel-Branco examines the rapidly changing and vigorously debated epistemological role of mathematics in the $17^{\text {th }}$ century as it applied to early modern medicine and particularly to Steno's accomplishments in anatomy. He shows how Steno used mathematics to reveal the structure of muscle and to show that glandular activity involved "humours," that is fluids, in a way that advanced the scientific understanding of the structure of the human body beyond the Cartesian model which oversimplified it as a machine. This approach by numbers in the study of the animal body, is argued, preceded Steno's first arrival in Italy.

Troels Kardel relates that Steno used mathematics to describe anatomical structures at microscopic scales not easily studied given the state of the instrumentation at the time, and so to leave him to hypothesize the existence of various anatomical transformations, among them, as Kardel has previously reported, and which he reinforces here, Steno's geometrical model whereby muscles contract by fiber shortening, not by a change in volume induced by animal spirits as was commonly speculated in the $17^{\text {th }}$ century. Kardel emphasizes that Steno's mathematically inspired insight led him to propose time-related changes in organic and inorganic materials - even some that were too fast and others too slow to be observed by any individual. Yet many, including Steno's model of fiber shortening, were confirmed centuries later. In short, Steno used the predictive potential of geometric modeling to position himself on the verge of understanding time-related physiological changes in the human body.

Steno's embrace of Galilean methodology also facilitated his ascertainment of the founding principles of modern stratigraphy (what we now call original horizontality, superposition, and lateral continuity of sedimentary strata), paleontology (fossils are the remains of once-living things), and crystallography (constancy of interfacial angles in crystals, and anisotropic variations in crystal growth from accretion rather than by vegetative growth from within) - long before they became formal sciences.

Steno was of course neither always the first nor the only one to transition to modernity, but his steadfast Galilean natural philosophy elevated him to prominence. Silvio Menchetti states that Steno was the first to formulate constancy of interfacial angles of crystals, specifically for quartz and implicitly for hematite, but that he did not generalize his observations sufficiently to constitute expression of the universal law of interfacial 
angles. Menchetti believes that distinction belongs to later and more comprehensive studies by Romé de l'Isle (1736-1790). However, Menchetti asserts that Steno's discussion of crystal growth provides a more secure claim to his fame. That is, although Steno carefully considered Aristotelian causes in formation of crystals: material, formal, efficient, and final, he nevertheless concluded that crystals do not grow vegetatively from within, but by accretion of deposits from external fluids. Furthermore, Steno correctly theorized that crystal faces grow anisotropically (at various rates, accounting for different sizes and shapes of similar faces in different specimens, while maintaining constancy of interfacial angles).

Stefano Dominici's study indicates that Steno also studied fossil and modern shells and bones given to him by Giovanni Alfonso Borelli of the Accademia del Cimento and that he knew about Tuscan fossiliferous localities from reading of late Renaissance authors. Dominici proposes that Steno had planned geological fieldwork in Tuscany and that his geological works aimed also at attesting the veridicity of the biblical narrative. In that view, Steno's observations on fossils and strata did not start after the dissection of a shark's head, as it is generally assumed. For Steno the processes of transport and accumulation of sediments were consistent with the separation of the Aristotelian elements, earth and water, on the third day of creation according to Scriptures. Similarly, his recognition that "glossopetrae" were not simulacra of shark teeth molded by Aristotelian vital forces within the earth but were actually the dental remains of sharks that once lived in the waters of the Deluge, the second universal sea of Scriptures. Steno regarded the flood as scientifically consistent with the "freedom and powers" of the "First Mover," the divinity. Steno's description of the structure of Tuscan sedimentary strata involved relative age dating (organizing events in sequence), but he also tackled duration of that history (what is now called "absolute time"), albeit consistent with the 5,000-year age of the earth as described in Scriptures.

Alan Cutler's paper finds the beginnings of the modern rock cycle in Steno's study of Tuscan strata. Although neither Steno nor any of his contemporaries understood igneous or metamorphic processes, Steno nevertheless understood the role of erosion, transport, and deposition in the production of rocks that we now classify as sedimentary. Thus, Steno began the generative classification of rocks, or classification of rocks by method of origin, in this case the derivation of rock from pre-existing earth materials and thus the cyclicity of the earth processes that we now accept today. Cutler points out that such generative classifications are unique to geology. Specifically, Steno explicitly stated that structural characteristics of rocks and fossils reveal their place and mode of origin. Although Steno accepted that these cyclic processes started after the "malediction of earth" due to the curse of Adam, Cutler presents evidence that Steno was onto not only a modern understanding of relative time (e.g., his principles of molding and sufficient similarity as well as superposition, original horizontality and lateral continuity), but also a clear understanding that the duration of earth processes varies from instantaneous to prolonged (now known as "deep time"). In Steno's case the biblical narrative of 5,000 years since the creation framed his conception of deep time. Cutler's point is that Steno nevertheless understood time as a scale-independent concept in a way that is critical to modern geoscience and distinctive of it, in this example that the rock cycle has no set time frame. All of this is integral to our modern understanding of earth history: short-term and inconspicuous processes, instantaneous catastrophic events, and slow changes which take place over eons all play a role in earth history.

Desmond Moser finds a fundamental analogy in Steno's Prodromus between microstructural surfaces in crystals and surfaces of sedimentary strata and that Steno's recognition of it was "implicit in the Prodromus but not always recognized." His interpretation gives a coherence to Steno's diagrams in the Prodromus of crystals, some showing surfaces constituting zonation, and sedimentary strata showing layering. Moser tabulates Steno's references to chemical as well as structural micro- and megascopic layerings in various materials that Steno recognized were useful in establishing timeseries (historical) sequences of formation - relative geochronology that is scale invariant in respect of both space and time.

Moser asserts that Steno's presentation amounts to a "revolutionary perception of scale invariance among the processes of solid formation in nature.” Further, Steno's "observational acuity" combined with the "provenance of his [Galilean] philosophy" facilitated his recognition of geologic history which continues to be fundamental and evident to the present day in both relative (sequential) and absolute (durational) geochronologies at scales ranging from microcrystalline to regional geographic and on to planetary levels. Moser quotes Steno in saying, "...these representations respond to a sign as if the macrocosmos laid hidden in the microcosmos," manifestation of a long philosophical history in which the human body has been regarded as a model for "the animate earth."

The result is a collection of papers on the cultural environment that Steno found in Italy and on his previous experiences, how he innovated the discourse on 
minerals and fossils, and the geometric, scale-independent approach that stemmed from his published works, one that continues to be taught at universities around the world. The historical interval embraced by the different contributions spans from the early seventeenth century in Rome, at the Accademia dei Lincei, includes an extensive discussion of Steno's science while in Florence, and ends at our time on Mars, where Steno's geometric, visual approach to reconstruct historical processes proves to be basic for planetary science. In short, the papers in this volume establish that Nicolaus Steno had a more foundational insight into the modern concept of natural history than heretofore recognized. 